\title{
Glacier, fjord, and seismic response to recent large calving events, Jakobshavn Isbra, Greenland
}

\author{
J. M. Amundson, ${ }^{1}$ M. Truffer, ${ }^{1}$ M. P. Lüthi, ${ }^{2}$ M. Fahnestock, ${ }^{3}$ M. West, ${ }^{1}$ and R. J. Motyka ${ }^{1}$ \\ Received 8 July 2008; revised 16 September 2008; accepted 1 October 2008; published 18 November 2008.
}

[1] The recent loss of Jakobshavn Isbræ's extensive floating ice tongue has been accompanied by a change in near terminus behavior. Calving currently occurs primarily in summer from a grounded terminus, involves the detachment and overturning of several icebergs within 30-60 min, and produces long-lasting and far-reaching ocean waves and seismic signals, including "glacial earthquakes". Calving also increases near-terminus glacier velocities by $\sim 3 \%$ but does not cause episodic rapid glacier slip, thereby contradicting the originally proposed glacial earthquake mechanism. We propose that the earthquakes are instead caused by icebergs scraping the fjord bottom during calving. Citation: Amundson, J. M., M. Truffer, M. P. Lüthi, M. Fahnestock, M. West, and R. J. Motyka (2008), Glacier, fjord, and seismic response to recent large calving events, Jakobshavn Isbræ, Greenland, Geophys. Res. Lett., 35, L22501, doi:10.1029/ 2008GL035281.

\section{Introduction}

[2] During the past decade Jakobshavn Isbræ (Greenlandic name: Sermeq Kujalleq) and numerous other outlet glaciers draining from the Greenland Ice Sheet have dramatically thinned, accelerated, and retreated, in some cases doubling their iceberg calving rates [Abdalati et al., 2001; Rignot and Kanagaratnam, 2006]. Although ice discharge accounts for roughly two-thirds of the mass loss from the Greenland Ice Sheet [Rignot and Kanagaratnam, 2006], calving processes, terminus stability, and related changes in glacier motion remain poorly understood. Consequently, controls on terminus dynamics have not been fully incorporated into predictions of Greenland's future mass balance and therefore current models may considerably underestimate future sea level rise [Intergovernmental Panel on Climate Change, 2007; Rahmstorf, 2007].

[3] Jakobshavn Isbræ (Figure 1a), which drains $7 \%$ of the Greenland Ice Sheet [Bindschadler, 1984], began a calving retreat in the 1990's [Luckman and Murray, 2005] after roughly 50 years of terminus stability [Sohn et al., 1998]. Initial thinning [Thomas, 2004] and acceleration [Joughin et al., 2004] of the glacier has been followed by the collapse of an extensive floating tongue and over $10 \mathrm{~km}$ of terminus retreat [Csatho et al., 2008]. The terminus, which now fluctuates $\sim 5 \mathrm{~km}$ annually (double the pre-retreat fluctua-

\footnotetext{
${ }^{1}$ Geophysical Institute, University of Alaska Fairbanks, Fairbanks, Alaska, USA.

${ }^{2}$ Versuchsanstalt für Wasserbau, Hydrologie und Glaziologie, ETHZürich, Zürich, Switzerland.

${ }^{3}$ Institute for the Study of the Earth, Oceans and Space, University of New Hampshire, Durham, New Hampshire, USA.
}

Copyright 2008 by the American Geophysical Union. 0094-8276/08/2008GL035281\$05.00 tions [Sohn et al., 1998]), is floating in winter and grounded in late summer. These variations are visible in time-lapse photography: icebergs calved in summer often contain dirty basal ice and are smaller and more rounded (never tabular) than icebergs calved in winter. Furthermore, surveying measurements (discussed below) show that there is no vertical tidal motion of the terminus in summer. Calving that occurs in summer therefore differs from calving events that occurred prior to the loss of the glacier's extensive floating tongue, which persisted year round and calved tabular icebergs in summer [Hughes, 1986]. In this paper we characterize recent large calving events and the glacier, fjord, and seismic response to these events.

\section{Methods}

[4] During summer 2007 we deployed several instruments, all synchronized to UTC time, to study Jakobshavn Isbræ and its proglacial fjord (Figure 1a) before, during, and after large calving events. Three cameras took photos of the terminus and fjord every 10 minutes from 13 May to 8 June 2007, every hour from 8 June to 17 August 2007, every six hours from 23 August 2007 to 7 May 2008, and every 10 minutes from 7 May to 14 May 2008. Ocean and seismic waves from calving events were recorded with a tide gauge and a seismometer. A Keller DC-22 pressure sensor, which has a resolution of $0.002 \mathrm{~m}$, was placed in Ilulissat Harbor, $50 \mathrm{~km}$ west of the glacier terminus; it logged data every 10 minutes from 11 May to 22 August 2007. A Mark Products L22 3-component velocity seismometer was placed on bedrock $1 \mathrm{~km}$ south of the glacier terminus and ran with a sampling frequency of $200 \mathrm{~Hz}$ from 17 May to 17 August 2007 and $100 \mathrm{~Hz}$ from 22 August to 22 November 2007 and from 9 April to 9 May 2008. The data gap in winter was due to a loss of battery power. The instrument has a natural frequency of $2 \mathrm{~Hz}$ and a sensitivity of $88 \mathrm{~V} \mathrm{~s} \mathrm{~m}^{-1}$.

[5] Optical and GPS surveys were conducted to monitor iceberg and glacier motion. Six survey reflectors were placed on the lower $4 \mathrm{~km}$ of the glacier and surveyed every 15 minutes with a Leica automatic theodolite from 15 May to 9 June 2007. Nine dual-frequency GPS receivers were deployed higher on the glacier, five on the main flow line and four on a perpendicular transect. These units were installed between 22 May and 1 June 2007 and, except for three that failed in July, ran until 23 August 2007. Additionally, two telemetered GPS units were placed on large icebergs; data from these were retrieved from 29 May to 8 June 2007. All GPS units logged position data every 15 seconds. The data were differentially corrected against one of two base stations located on opposite sides of the fjord. The measurement uncertainties of the optical and GPS 

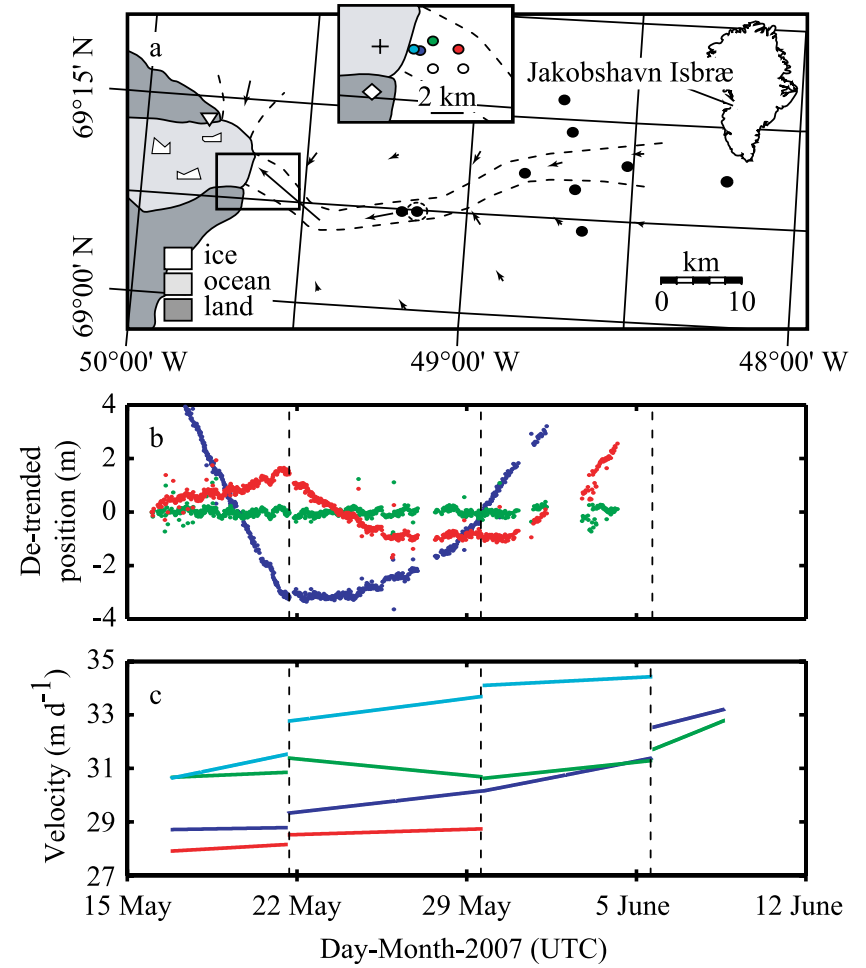

Figure 1. Jakobshavn Isbræ and motion surveying data. (a) Map showing locations of the glacier GPS (black circles), iceberg GPS (plus sign), southern (diamond) and northern (triangle) GPS base stations, and optical survey markers (circles in the inset). A seismometer and cameras were located near the southern base station. Arrows roughly indicate the ice flow direction and relative magnitude. Dashed lines mark the margins of fast moving ice. (b) Detrended along-flow positions for the near terminus marker (light blue circle in Figure 1a), assuming constant velocity (blue), constant but non-zero strain rate (red), and strain rates that change at each calving event but otherwise remain constant and non-zero (green). Calving events are indicated by dashed lines. The root mean square errors are 3.06, 0.86, and $0.12 \mathrm{~m}$, respectively. Note the break in slope of the red and blue curves on 21 May. Data gaps are due to bad weather. (c) Velocity of the four fastest survey markers (line colors correspond to markers in Figure 1a).

surveys were estimated by de-trending several days of data at a time, removing extreme outliers that clearly indicate bad surveys, and calculating the root mean square errors. The errors for the optical and GPS surveys were $\pm 0.15 \mathrm{~m}$ and $\pm 0.02 \mathrm{~m}$, respectively.

\section{Description of Calving Events}

[6] We documented 32 large calving events between 13 May 2007 and 14 May 2008 (Table S1 of the auxiliary material) ${ }^{1}$ with time-lapse photography and passive seismology. Seven events, including one in 2006, were directly observed. Twenty-five events occurred between 16 May and 2 August 2007, or at a mean rate of about one every

\footnotetext{
${ }^{1}$ Auxiliary materials are available in the HTML. doi:10.1029/ 2008GL035281.
}

75 hours. The calving rate greatly decreased in winter: three events occurred between 17 August and 17 October 2007 and no additional events occurred until April 2008. The short floating tongue that developed over winter disintegrated in a sequence of four calving events between 19 April and 10 May 2008.

[7] Hereafter we focus on calving that occurred in summer from a grounded terminus. We observed calving icebergs that penetrated the entire glacier thickness $(\sim 900 \mathrm{~m}$, see below) and were a kilometer in lateral width and several hundred meters in the flow direction (Figure 2). The calving events typically lasted 30-60 min, during which several of these icebergs calved and overturned (top toward or away from the terminus). Each iceberg rotated $90^{\circ}$ within 5 min (Figures $2 \mathrm{c}-2 \mathrm{f}$ ), displaced up to $\sim 0.5 \mathrm{~km}^{3}$ of water, and lost more than $10^{14} \mathrm{~J}$ of potential energy. As a result the icebergs sprayed water and ice particles over the $100 \mathrm{~m}$ high terminus, produced ocean waves with local amplitudes of several meters and periods greater than $30 \mathrm{~s}$ (Movies S1 and S2), and propelled most icebergs in the ice-choked fjord rapidly down fjord ( $\sim 2 \mathrm{~km}$ in an hour, Figure S1). Icebergs near the terminus abruptly decelerated once the events ended (Movie S2). On one occasion (17 August 2007) icebergs at the fjord mouth $50 \mathrm{~km}$ away were observed moving $1-2 \mathrm{~km} \mathrm{hr}^{-1}$ several hours after an event. Furthermore, waves from all events were detected by our tide gauge $30 \mathrm{~min}$ after calving initiated and for a duration of six hours (with amplitudes much reduced, Figure S2). Similar waves have been attributed to, but not correlated with, calving [Sørensen and Schrøder, 1971]. In contrast, between events icebergs in the upper fjord were pushed forward at the same speed as the advancing terminus ( $\sim 35 \mathrm{~m} \mathrm{~d}^{-1}$, see Figure S1 and below).

[8] A similar calving event was recently observed at Columbia Glacier, Alaska, as its terminus became buoyant (T. Pfeffer, personal communication, 2008). More commonly, though, large calving events observed at grounded tidewater glaciers in Alaska involve the top, middle, and bottom parts of the termini calving separately and in succession within 5-30 min [O'Neel et al., 2003].

[9] Our local, land-based seismometer recorded unique seismic signals originating from the calving events. The seismograms are characterized by (1) emergent, cigarshaped envelopes that last about as long as the calving events (up to an hour) and have several peaks, (2) high energy between 0.5 and $30 \mathrm{~Hz}$ with maximum energy at $\sim 4 \mathrm{~Hz}$, (3) ground motion that, at low frequencies, is preferentially-oriented perpendicular to the fjord walls, (4) continuously elevated seismic activity for several hours after calving (sometimes over 24 hours) (Figure 3), (5) resemblance to seismograms produced by icebergs overturning in the fjord (Figure S3) during periods of no calving, and (6) occasionally have one or two high amplitude spikes that document maximum ground motion during the events and contain significant energy below $1 \mathrm{~Hz}$ (Figures $3 \mathrm{c}-3 \mathrm{f}$ ). Characteristics (1) and (2) are in good agreement with observations at Columbia Glacier [Qamar, 1988; O’Neel et al., 2007]. While these seismograms may be a result of water-driven fracture propagation [O'Neel et al., 2007], characteristics (1) and (3)-(5) suggest that much of the local seismic signal is instead caused by the loading and unloading of the coast by large ocean waves [e.g., Yuan et 

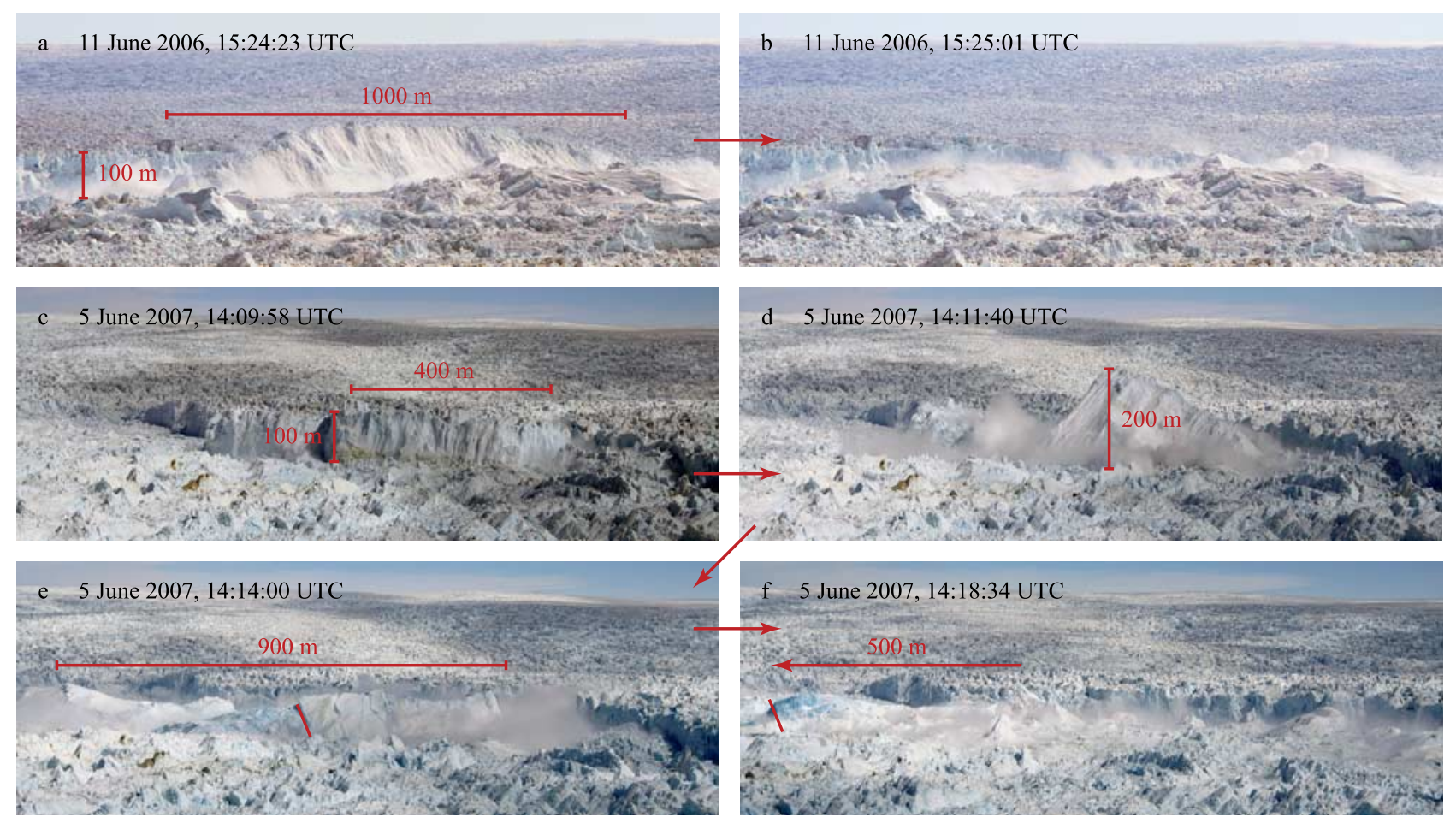

Figure 2. Imagery of calving events. (a and b) A calving event on 11 June 2006. Photos were taken from the north side of the fjord. The time stamps may differ from UTC by 1-2 min. (c-f) The third of three calving events on 5 June 2007. Photos were taken from the south side of the fjord. The time stamps are within seconds of UTC. In Figure 2f, the arrow represents the distance that the notch in the iceberg (marked in red) traveled between frames Figure $2 \mathrm{e}$ and Figure $2 \mathrm{f}$.

$0.1 \mathrm{~Hz}$ high-pass-filtered vertical component of seismogram
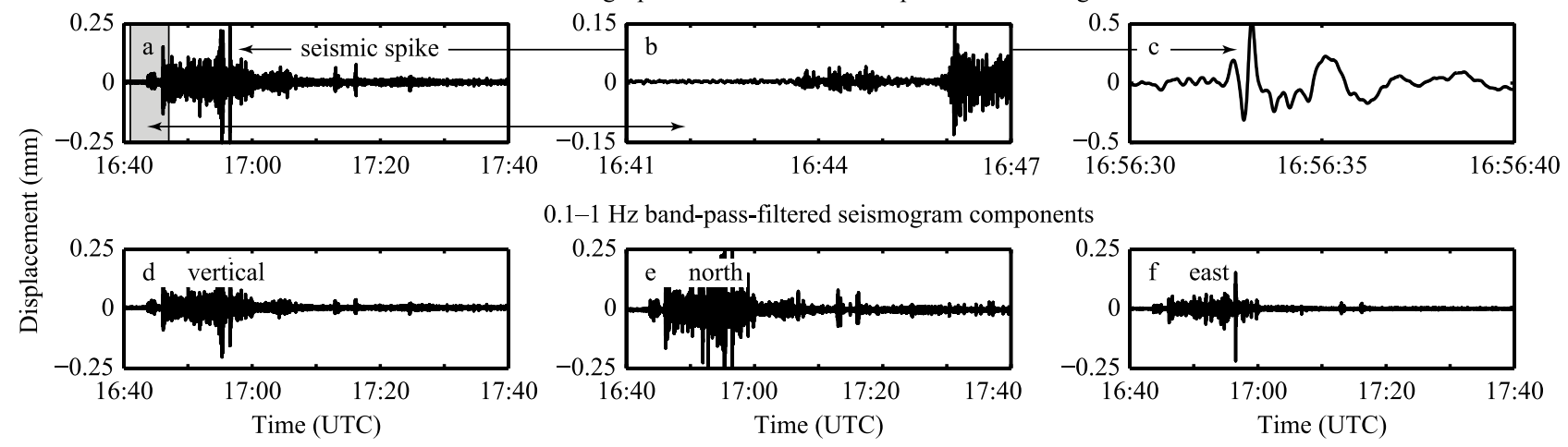

0.1-1 Hz band-pass-filtered seismogram components

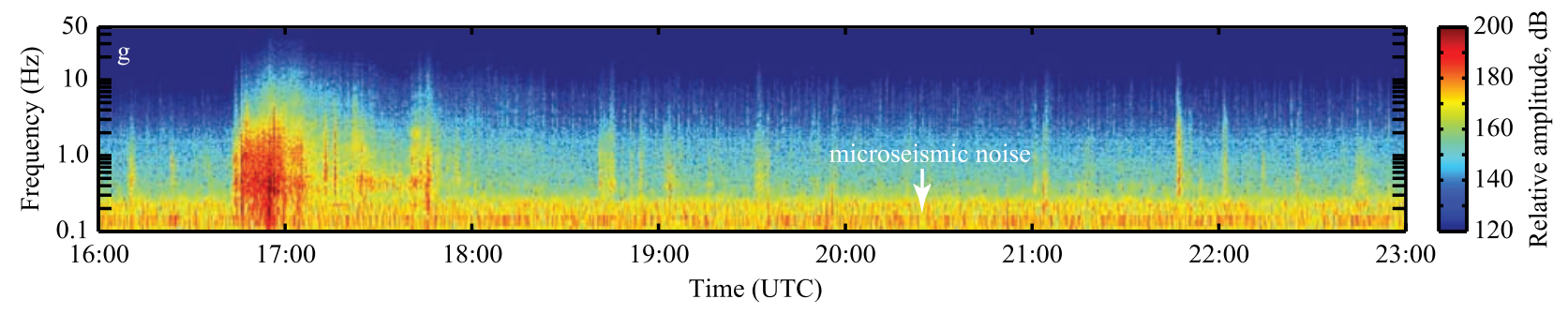

Figure 3. Seismogram from the 4 July 2007 calving event. The data were corrected for instrument response and integrated. (a) $0.1 \mathrm{~Hz}$ high-pass-filtered vertical seismogram component that had (b) an emergent onset and (c) a highamplitude seismic spike. $0.1-1 \mathrm{~Hz}$ band-pass filtered (d) vertical, (e) north, and (f) east seismogram components. The fjord walls run roughly east-west. (g) Spectrogram of the calving event. Note the slightly elevated energy content that lasted for several hours after the calving event. 
al., 2005], which may disturb the densely-packed fjord for hours. We propose that the emergent, cigar-shaped envelopes reflect the gradual growth and decay of ocean waves during calving events and that the peaks reflect the detachment and overturning of individual icebergs.

[10] Seismograms of glacial earthquakes (discussed below) closely resemble local and far-field seismograms from calving events (Figure S4). This more tightly-constrains the observation that glacial earthquakes are associated with calving [Joughin et al., 2008]. Not all calving events produce glacial earthquakes and furthermore, glacial earthquakes only occupy short time windows within the locally recorded seismograms (e.g., the spike in Figure $3 \mathrm{c}$ is a candidate for a glacial earthquake).

[11] In contrast to the activity at the terminus and in the fjord, changes in glacier motion associated with calving were small. At no time before, during, or after calving did any of the glacier survey markers experience jumps in horizontal position larger than the error of the survey measurements $( \pm 0.15 \mathrm{~m}$ and $\pm 0.02 \mathrm{~m}$ for the nearterminus optical and up-glacier GPS surveys, respectively) (Figures 1b, S5, and S6). However, the position plots for the near-terminus markers do show breaks in slope, which are indicative of step changes in velocity, that coincide with calving events (Figures $1 \mathrm{~b}$ and S5). To quantify the step changes, we split the data into intervals bounded by calving events, rotated them into along- and across-flow directions, and assumed that the velocity at fixed points in space remains constant between calving events. Thus, the total derivative of a marker's along-flow velocity within each interval is

$$
\frac{D u}{D t}=\frac{\partial u}{\partial x} \frac{d x}{d t}+\frac{\partial u}{\partial t}=\dot{\epsilon}_{x x} u
$$

where $x, u$, and $\dot{\epsilon}_{x x}$ are the along-flow position, velocity, and extensional strain rate, and $t$ is time. Integrating twice gives

$$
x(t)=\frac{u_{0}}{\dot{\epsilon}_{x x}}\left[\exp \left(\dot{\epsilon}_{x x}\left(t-t_{0}\right)\right)-1\right]+x_{0} .
$$

$x_{0}, u_{0}$ and $\dot{\epsilon}_{x x}$ are found for each interval by fitting Equation 2 through the position data. The results are used to calculate $u(t)$ (Figure 1c).

[12] The glacier velocity was $\sim 35 \mathrm{~m} \mathrm{~d}^{-1}$ near the terminus (Figure 1c), decreasing to $20-25 \mathrm{~m} \mathrm{~d}^{-1}$ just $4 \mathrm{~km}$ upglacier. During calving events the velocities of the markers increased by $\sim 3 \%\left(0.5-1.5 \mathrm{~m} \mathrm{~d}^{-1}\right)$. Changes were largest for markers located closest to the terminus and were only detectable within $3-4 \mathrm{~km}$ of the terminus. The velocity changes were comparable to multiplying the longitudinal strain rate at a survey marker by the amount of terminus retreat from a given calving event. We therefore attribute the velocity changes to the glacier rapidly adjusting its stress field as the terminus (a free boundary) moves up glacier.

\section{Calving-Induced Glacial Earthquakes}

[13] Our surveying data contradicts the hypothesis that teleseismic glacial earthquakes are generated by glaciers sliding several decimeters to several meters within minutes [Ekström et al., 2003, 2006; Tsai and Ekström, 2007], possibly in response to calving [Joughin et al., 2008; Tsai et al., 2008]. Such earthquakes are characterized by long period (35-150 s), large magnitude $\left(M_{s w} 4.6-5.1\right)$ tremors that originate from the terminal regions of major outlet glaciers in Greenland (including Jakobshavn Isbræ), occur predominantly in summer, have occurred more frequently as the glaciers have retreated [Ekström et al., 2003, 2006; Tsai and Ekström, 2007], and appear to be associated with the calving of large, overturning icebergs from grounded termini [Joughin et al., 2008]. Far-field seismic waveforms from the earthquakes can be fit with mass-sliding models using force vectors that are horizontal and parallel to the glacier flow lines [Ekström et al., 2003, 2006; Tsai and Ekström, 2007].

[14] We propose the alternative hypothesis, consistent with these and our observations, that glacial earthquakes are generated by icebergs overturning (also proposed by Tsai et al. [2008]) and scraping the fjord bottom during calving. Hydrostatic imbalance during overturning greatly increases the energy of a calving iceberg and, furthermore, icebergs that calve from a grounded or nearly-grounded terminus and penetrate the entire glacier thickness must scrape the fjord bottom as they overturn. Our hypothesis is also consistent with the observation that most known glacial earthquakes that originated near Jakobshavn Isbræ occurred as the glacier was retreating past a shallow pinning point [Luckman and Murray, 2005; Tsai and Ekström, 2007].

[15] The calving icebergs in Figure 2 penetrated the entire ice thickness and brought dirt to the fjord surface. Thus they were approximately $900 \mathrm{~m}$ thick: the glacier was $1000 \mathrm{~m}$ thick in the late 1980's at what is now the terminus [Clarke and Echelmeyer, 1996] and has since thinned by $100 \mathrm{~m}$ [Thomas, 2004]. Furthermore, since the terminus is grounded during summer, the water depth must not exceed about $800 \mathrm{~m}$. Icebergs that are $900 \mathrm{~m}$ thick by $400 \mathrm{~m}$ along flow (e.g., Figures $2 \mathrm{c}-2 \mathrm{f}$ ) achieve a maximum total vertical dimension of $985 \mathrm{~m}$ during overturning; the icebergs can therefore reach $\sim 200 \mathrm{~m}$ above sea level by pushing off the fjord bottom during calving. The iceberg in Figures $2 \mathrm{a}$ and $2 \mathrm{~b}$ rotated $45^{\circ}$ in $30-40 \mathrm{~s}$; it had a rotational kinetic energy of $5.0-9.0 \times 10^{12} \mathrm{~J}(1000 \mathrm{~m}$ wide, $900 \mathrm{~m}$ high, $400 \mathrm{~m}$ long). For comparison, a tabular iceberg that ran aground in Antarctica had a kinetic energy of $1.1 \times 10^{13} \mathrm{~J}$ prior to grounding and produced a moderately sized earthquake $\left(\mathrm{M}_{l}\right.$ 3.6) containing low-frequency tremors $(<0.5 \mathrm{~Hz})$. The iceberg contained four orders of magnitude more energy than was needed to produce the $\mathrm{M}_{l} 3.6$ earthquake [Müller et al., 2005]. Thus some calving icebergs contain enough energy to produce glacial earthquakes.

\section{Conclusions}

[16] Calving at Jakobshavn Isbræ involves the detachment and overturning of several large icebergs within 30-60 min, causes most icebergs in the ice-choked fjord to move $2 \mathrm{~km}$ in an hour, produces ocean waves that are detectable $50 \mathrm{~km}$ away, and emits long-lasting and farreaching seismic signals. It is now clear that teleseismic glacial earthquakes are generated during calving events, although the specific source mechanism remains unclear [Tsai et al., 2008]. Despite the large amount of energy released during calving there is little response from the 
glacier, thus indicating that glacial earthquakes are not caused by episodic rapid glacier slip [e.g., Ekström et al., 2003]. The observations presented here are an important step toward assessing the mechanisms controlling calving at major outlet glaciers in Greenland.

[17] Acknowledgments. We thank J. Brown and D. Maxwell for field assistance, and S. Anandakrishnan, A. Behar, and R. Fatland for loaning GPS receivers. Comments from editor E. Rignot and reviewers S. O'Neel and T. Pfeffer improved the manuscript. Logistics and instrumental support were provided by VECO Polar Resources, UNAVCO, and PASSCAL. Seismic analysis was done with the Matlab waveform object package written by C. Reyes (http://www.giseis.alaska.edu/Seis/EQ/tools/matlab/). Funding was provided by NASA's Cryospheric Sciences Program (NNG06GB49G), the U.S. National Science Foundation (ARC0531075), the Swiss National Science Foundation (200021-113503/1), the Comer Science and Education Foundation, and a CIFAR IPY student fellowship under NOAA cooperative agreement NA17RJ1224 with the University of Alaska.

\section{References}

Abdalati, W., W. Krabill, E. Frederick, S. Manizade, C. Martin, J. Sonntag, R. Swift, R. Thomas, W. Wright, and J. Yungel (2001), Outlet glacier and margin elevation changes: Near-coastal thinning of the Greenland ice sheet, J. Geophys. Res., 106(D24), 33729-33741.

Bindschadler, R. A. (1984), Jakobshavns Glacier drainage basin: A balance assessment, J. Geophys. Res., 89(C2), 2066-2072.

Clarke, T. S., and K. Echelmeyer (1996), Seismic-reflection evidence for a deep subglacial trough beneath Jakobshavn Isbræ, West Greenland, J. Glaciol., 42(141), 219-232.

Csatho, B., T. Schenk, C. J. van der Veen, and W. B. Krabill (2008), Intermittent thinning of Jakobshavn Isbræ, West Greenland, since the Little Ice Age, J. Glaciol., 54(184), 131-144.

Ekström, G., M. Nettles, and G. A. Abers (2003), Glacial earthquakes, Science, 302(5645), 622-624, doi:10.1126/science.1088057.

Ekström, G., M. Nettles, and V. Tsai (2006), Seasonality and increasing frequency of glacial earthquakes, Science, 311(5768), 1756-1758, doi:10.1126/science.1122112.

Hughes, T. (1986), The Jakobshavns effect, Geophys. Res. Lett., 13(1), 4648.

Intergovernmental Panel on Climate Change (2007), Climate Change 2007: The Physical Science Basis. Contribution of Working Group I to the Fourth Assessment Report of the Intergovernmental Panel on Climate Change, edited by S. Solomon et al., 996 pp. , Cambridge Univ. Press, Cambridge, U. K.

Joughin, I., W. Abdalati, and M. Fahnestock (2004), Large fluctuations in speed on Greenland's Jakobshavn Isbræ Glacier, Nature, 432, 608-610, doi: $10.1038 /$ nature 03130 .

Joughin, I., I. Howat, R. B. Alley, G. Ekström, M. Fahnestock, T. Moon, M. Nettles, M. Truffer, and V. C. Tsai (2008), Ice-front variation and tidewater behavior on Helheim and Kangerdlugssuaq glaciers, Greenland, J. Geophys. Res., 113, F01004, doi:10.1029/2007JF000837.
Luckman, A., and T. Murray (2005), Seasonal variation in velocity before retreat of Jakobshavn Isbræ, Greenland, Geophys. Res. Lett., 32, L08501, doi:10.1029/2005GL022519.

Müller, C., V. Schlindwein, A. Eckstaller, and H. Miller (2005), Singing icebergs, Science, 310(5752), 1299, doi:10.1126/science.1117145.

O’Neel, S., K. A. Echelmeyer, and R. J. Motyka (2003), Short-term variations in calving of a tidewater glacier: LeConte Glacier, Alaska, U.S.A., J. Glaciol., 49(167), 587-598.

O'Neel, S., H. P. Marshall, D. E. McNamara, and W. T. Pfeffer (2007), Seismic detection and analysis of icequakes at Columbia Glacier, Alaska, J. Geophys. Res., 112, F03S23, doi:10.1029/2006JF000595.

Qamar, A. (1988), Calving icebergs: A source of low-frequency seismic signals from Columbia Glacier, Alaska, J. Geophys. Res., 93(B6), 66156623

Rahmstorf, S. (2007), A semi-empirical approach to projecting future sealevel rise, Science, 315(5810), 368-370, doi:10.1126/science.1135456.

Rignot, E., and P. Kanagaratnam (2006), Changes in the velocity structure of the Greenland Ice Sheet, Science, 311(5763), 986-990, doi:10.1126/ science. 1121381 .

Sørensen, T., and H. Schrøder (1971), Long period wave phenomena in Jakobshavn Harbour Bay, Greenland, in Proceedings from the First International Conference on Port and Ocean Engineering under Arctic Conditions, pp. 1312-1324, Tech. Univ. of Norway, Trondheim, Norway.

Sohn, H. G., K. C. Jezek, and C. J. van der Veen (1998), Jakobshavn Glacier, West Greenland: 30 years of spaceborne observations, Geophys. Res. Lett., 25(14), 2699-2702.

Thomas, R. H. (2004), Force-perturbation analysis of recent thinning and acceleration of Jakobshavn Isbræ, Greenland, J. Glaciol., 50(168), 5766.

Tsai, V. C., and G. Ekström (2007), Analysis of glacial earthquakes, J. Geophys. Res., 112, F03S22, doi:10.1029/2006JF000596.

Tsai, V. C., J. R. Rice, and M. Fahnestock (2008), Possible mechanisms for glacial earthquakes, J. Geophys. Res., 113, F03014, doi:10.1029/ 2007JF000944.

Yuan, X., R. Kind, and H. A. Pedersen (2005), Seismic monitoring of the Indian Ocean tsunami, Geophys. Res. Lett., 32, L15308, doi:10.1029/ 2005 GL023464.

J. M. Amundson, R. J. Motyka, M. Truffer, and M. West, Geophysical Institute, University of Alaska Fairbanks, 903 Koyukuk Drive, Fairbanks, AK 99775, USA. (amundson@gi.alaska.edu)

M. Fahnestock, Institute for the Study of the Earth, Oceans and Space, University of New Hampshire, 39 College Road, Durham, NH 03824, USA.

M. P. Lüthi, Versuchsanstalt für Wasserbau, Hydrologie und Glaziologie, ETH-Zürich, Gloriastrasse 37-39, CH-8092 Zürich, Switzerland. 